\title{
Mycorrhizal Hyphal Length as a Function of Plant Community Richness and Composition in Restored Northern Tallgrass Prairies (USA)
}

\author{
Marcus A. Bingham ${ }^{1}$ and Mario Biondini ${ }^{2}$ \\ Authors are ${ }^{1}$ Doctoral candidate, Department of Forest Sciences, University of British Columbia, Vancouver, BC V6T 1Z4 Canada; and ${ }^{2}$ Professor, \\ School of Natural Resource Sciences, North Dakota State University, Fargo, ND 58105, USA.
}

\begin{abstract}
We assessed the total length of external arbuscular mycorrhizal hyphae as a function of plant species and functional form richness in restored northern tallgrass prairies. Total hyphal length increased with species and functional form richness. Hyphal length also increased when plant communities were dominated by species with high root density, high root to shoot ratios, and high nitrogen use efficiency. Hyphal length was positively correlated with the biomass of late successional $\mathrm{C}_{4}$ grasses (Andropogon gerardi Vitman, Panicum virgatum L., Schizachyrium scoparium [Michx.] Nash-Gould, and Sorghastrum nutans L.), which are obligately mycorrhizal and characterized by high root to shoot ratios, and high root surface area per unit of root biomass. We thus conclude that in order to recover extraradical arbuscular mycorrhizal hyphal length in restored northern tallgrass prairies, at least three factors need to be given priority: 1) achieving high levels of species and functional form richness; 2) making sure that late successional $\mathrm{C}_{4}$ grasses are present; and 3) making sure that the seed mixture includes species that are characterized by high root to shoot ratio, high root density, and high nitrogen-use efficiency.
\end{abstract}

\section{Resumen}

En este experimento evaluamos la relacion entre la longitud externa del micro micelio arbuscular simbiotico (mycorrhiza) y la diversidad de especies y formas funcionales de plantas en una pradera alta restaurada en el norte de los Estados Unidos. La longitud total del micro micelio subio con el incremento en la diversidad de especies y formas funcionales de plantas. La longitud total del micro micelio tambien subio cuando la comunidad de plantas estaba dominada por especies caracterizadas por una elevada densidades the raices, altas proportion de raices, y alta eficiencia en el uso del nitrogeno. Econtramos tambien que la longitud total del micro micelio estaba correlacionada con la biomasa de herbajes $\mathrm{C}_{4}$ tipicas del los finales estados de sucesion en estas praderas (Andropogon gerardi Vitman, Panicum virgatum L., Schizachyrium scoparium [Michx.] NashGould, y Sorghastrum nutans L.). Estos herbajes se caracterizan por ser dependientes en micelio arbuscular simbiotico, altas proporciones de raices, y superficie de raices por unidad the masa de raices. Concluimos que para reestablecer adquados niveles de micro micelio arbuscular simbiotico en las praderas altas del norte de los Estados Unidos al menos tres elementos son necesarios: 1) altos niveles de diversidad the especies y formas funcionales de plantas; 2) la presencia de herbajes $\mathrm{C}_{4}$ tipicas del los finales estados de sucesion; y 3) asegurar que la mesclas de especies plantadas incluye especies caracterizadas por una alta proporcion de raices, alta densidad de raices, y alta efeciencia en la utilizacion del nitrogeno.

Key Words: Arbuscular mycorrhiza, external hyphae, functional form diversity, northern tallgrass prairie restoration, species diversity

\section{INTRODUCTION}

The hypothesis that the function and sustainability of natural and managed ecosystems might depend on their biological diversity has been part of ecological theory for more than $100 \mathrm{yr}$ (Tilman et al. 1998). The issue has recently taken center stage due to an increase in the replacement of natural ecosystems with restored and managed ones. Cumulative results from a variety of well controlled experiments such as the US Long Term Ecological Research, Cedar Creek (Tilman et al. 1996), the European Bio-Diversity and Ecological Processes in Terrestrial Herbaceous Ecosystems (Spehn et al.

Research was funded by grants from the National Science Foundation (DEB-9627928), and USDA-NRICGP (93-0051 and 99-00979) to M. Biondini.

Correspondence: Mario Biondini, School of Natural Resource Sciences, North Dakota State University, NDSU Dept 7650, PO Box 6050, Fargo, ND 58105-6050, USA. Email: Mario.Biondini@ ndsu.edu

Manuscript received 31 March 2008; manuscript accepted 17 October 2008.
2005), and northern tallgrass prairie restoration project (Biondini 2007) have improved our understanding of this problem, in particular the relationship among plant diversity, production, stability, and susceptibility to invasion. The question regarding the mechanisms by which biodiversity affects ecosystem functioning has stimulated intense argument and is still a subject of much uncertainty (Hooper et al. 2005). One way by which plants can potentially increase ecosystem productivity and stability is by forming mycorrhizal associations (van der Heijden et al. 1998; Eriksson 2001; Hartnett and Wilson 2002). Plants are most likely to form associations with and benefit from mycorrhizal fungi under conditions in which availability of one or more soil nutrients, including water, is low (Hoeksema and Schwartz 2003; Jones and Smith 2004). There are at least two primary situations in which this might occur. One is in environments with a low frequency of disturbance and high abiotic stress, where soil nutrients are not sufficient to support high aboveground growth rates and carbon $(\mathrm{C})$ allocation to belowground biomass is usually 
proportionately greater (Grime 1977). The other involves conditions where disturbance is at intermediate to low frequencies and abiotic stress is low, thereby facilitating an environment where aboveground growth rates are high, and competition favors increased root surface area for nutrient uptake to maintain these growth rates as plant community succession progresses.

High-production grasslands fall under this second category, and most late successional plant species growing in these communities are known to be obligatory or facultative mycorrhizal (Hartnett and Wilson 2002). Although benefits of arbuscular mycorrhizal (AM) fungi to specific plant species in these grasslands vary with community composition and density (Hartnett et al. 1993; Hartnett and Wilson 2002), it likely is that their presence is contributing to overall community production, regardless of the individual plant species that are incurring a benefit or a cost. Stability of the community is also likely to increase as the effects of spatial variability are dampened by the greater volume of the soil being accessed by hyphae. Stability might be further amplified if common mycorrhizal networks are formed between plants with different life history patterns and climatic tolerances. External arbuscular mycorrhizal (EAM) hyphae also produce recalcitrant forms of C, such as chitin and glomalin (Wright and Upadhyaya 1998; Zhu and Miller 2003), and therefore might be important contributors to the structural stability of the soil and C sequestration (Miller and Jastrow 1992; Zhu and Miller 2003).

Hyphal length is an important consideration that needs to be integrated into any planning for grassland restoration because of 1) the potential contribution arbuscular mycorrhizal hyphal length could make to plant community production and stability; and 2) the reciprocal effects that plant diversity could have on hyphal length, leading to a more complete utilization of soil nutrients. The specific objectives of this study were 1) to investigate the relationship of species and functional form richness with EAM hyphal length in restored northern tallgrass prairie; and 2) to determine what combinations of growth rates, nutrient use efficiency, root architecture, and root physiology of plants are associated with higher EAM hyphal length. The working hypothesis was that EAM hyphal length would increase with increasing levels of species and functional form richness.

\section{METHODS}

\section{Experimental Design}

The experiment was located at the North Dakota State University (NDSU) Albert Ekre Grassland Preserve, in southeastern North Dakota (lat $97^{\circ} 7^{\prime} \mathrm{W}$, long $46^{\circ} 33^{\prime} \mathrm{N}$ ). The soils belong to the Embden-Tiffany fine sandy loam series (coarseloamy, mixed, superactive, frigid Pachic Hapludolls and frigid Typic Endoaquolls): 0-3\% slopes, moderately well-drained, and a combined A and B depth of $69 \mathrm{~cm}$. The area had been planted in the past with corn and soybeans. It was disked in 1997 and 1998 to reduce the seed bank, and was treated with Roundup (Monsanto; 18\% Glyphosate, 0.73\% Diquat, 0.3\% Imazapic) prior to planting to minimize plant regrowth.

This study used a portion of a much larger plant diversity experiment described in detail by Biondini (2007). That experiment was organized as a completely randomized factorial design with three factors, 10 replications per treatment, and two subreplications per replication, for a total of 400 plots. For the purpose of this study we used a subset of 50 plots from the low nitrogen $(\mathrm{N})$ treatment $\left(20 \mathrm{~kg} \cdot \mathrm{ha}^{-1} \cdot \mathrm{yr}^{-1}\right)$, and one subreplication of the species richness factor (Factor 3), which involved treatments with 1, 2, 5, 10, or 20 plant species. Each replication consisted of the given number of species drawn randomly from the list shown in Table 1 . Two introduced species, Bromus inermis Leyss and Agropyron cristatum (L.), were included in the list (Poa pratensis L. is considered a naturalized one) because 1) they are common in many restored grasslands (Redente et al. 1989; Johnson and Schwartz 1993); 2) the Bromus inermis propagule reservoir is so large that it becomes an issue whether planted or not; and 3) because of their prevalence, it is important to investigate how these species might shape, if at all, the relationship among diversity, production, and stability.

Levang-Brilz and Biondini (2002) used cluster analysis to classify these species into functional forms on the basis of the physiological, morphological, and growth parameters shown in Table 1 . The cluster analysis resulted in three statistically distinct groups for grasses (G1-G3), and three for forbs (F1F3) shown in Table 1. The G1 group of grasses was characterized by high $\rho$ (scaling constant relating root biomass to root surface area) and root to shoot biomass ratio (R:S), G2 by high $\beta$ (scaling constant relating root biomass to root lateral spread, high $\beta$ implies low root density), and G3 by high Imax$\mathrm{N}$ and Imax-P (N and phosphorous $[\mathrm{P}]$ uptake rates per unit of root surface area in $\left.\mathrm{g} \cdot \mathrm{m}^{-2} \cdot \mathrm{d}^{-1}\right)$. Because grasses are comprised of both $\mathrm{C}_{3}$ and $\mathrm{C}_{4}$ plants, they were reclassified into six functional forms by combining the $\mathrm{C}_{3} / \mathrm{C}_{4}$ classification with the G1-G3 classes. The F1 group of forbs was characterized by a high $\rho, F 2$ by high R:S, N-use efficiency (NUE), P-use efficiency (PUE; NUE and PUE in $\mathrm{g} \cdot \mathrm{g} \mathrm{N}^{-1}$ and $\mathrm{g} \cdot \mathrm{g} \mathrm{P} \mathrm{P}^{-1}$ respectively), and $\tau$ (scaling constant for root plasticity, $\tau=0$ no plasticity), and the F3 group by high relative growth rate $\left(\mathrm{g} \cdot \mathrm{g}^{-1} \cdot \mathrm{d}^{-1}\right)$, Imax-N, and Imax-P. For further details on how the cluster analysis was conducted, and the methodologies used to measure these parameters see Levang-Brilz and Biondini (2002), Johnson and Biondini (2001), and Biondini (2007).

Experimental plots were $9 \mathrm{~m}^{2}(3 \times 3 \mathrm{~m})$ with a 1 -m buffer zone. The seeding rates were 400 live seeds $\cdot \mathrm{m}^{-2}$, with equal amounts for each species. $\mathrm{N}$ and $\mathrm{P}$ were applied in the early spring of each year, just after the snow had melted, using Sierra ${ }^{\circledR}$ slow release fertilizer prills (Pursell Technologies, Inc.). The plots were planted in the fall of 1998 and spring of 1999, and sampled for the first time in 2000 to allow for a good establishment of the seeded species and prevent the uprooting of young plants.

\section{Plant Biomass Sampling}

Peak aboveground biomass by species was estimated by clipping four $0.25-\mathrm{m}^{2}$ quadrats per replication at the end of July or August (depending on the growing conditions for that year). The clipped biomass was separated by species and the materials processed using protocols described by Biondini (2007). The quadrats were randomly located within distinct 
Table 1. Species used in the experiment. FF represents the functional form types derived by Levang-Brilz and Biondini (2002) based on the morphological and physiological characteristics listed in this table. $\beta, \delta$, and $\rho$ are scaling constants that relate root biomass (RB $[\mathrm{g}])$ to root lateral spread (RLS $\left.[\mathrm{m}]=\alpha \mathrm{RB}^{\beta}\right)$, root length $\left(R L[m]=\gamma R^{\delta}\right)$, and root surface area $\left(R S A\left[m^{2}\right]=\eta R B^{\rho}\right)$, and $\tau$ is a scaling constant for root plasticity ( $\tau=0$ no plasticity) derived by Biondini (2001) using data from Johnson and Biondini (2001). R:S is the average root to shoot ratio; RGR is the average relative growth rate $\left(\mathrm{g} \cdot \mathrm{g}^{-1} \cdot \mathrm{d}^{-1}\right)$ for aboveground biomass

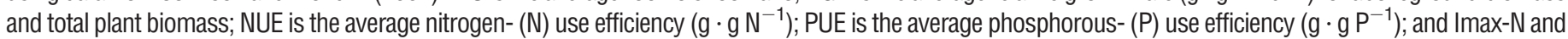
Imax-P are the maximum N or P uptake rate per unit of root surface area $\left(\mathrm{g} \cdot \mathrm{m}^{-2} \cdot \mathrm{d}^{-1}\right)$. Nomenclature follows the Great Plains Flora Association (1986).

\begin{tabular}{|c|c|c|c|c|c|c|c|c|c|c|c|c|}
\hline Species & $\mathrm{C}_{3} / \mathrm{C}_{4}$ & $\mathrm{FF}$ & $\beta$ & $\delta$ & $\rho$ & $R: S$ & RGR & NUE & PUE & Imax-N & Imax-P & $\tau$ \\
\hline \multicolumn{13}{|l|}{ Grasses } \\
\hline Agropyron cristatum & $\mathrm{C}_{3}$ & G1 & 0.007 & 0.562 & 0.589 & 0.81 & 0.11 & 44.41 & 181.03 & 0.3576 & 0.1082 & 0.28 \\
\hline Bromus inermis & $\mathrm{C}_{3}$ & G1 & 0.496 & 0.793 & 1.066 & 0.71 & 0.11 & 71.96 & 173.48 & 0.3695 & 0.0855 & 0.08 \\
\hline Hordeum jubatum & $\mathrm{C}_{3}$ & G1 & 0.667 & 0.401 & 0.719 & 0.87 & 0.15 & 54.58 & 129.28 & 0.2433 & 0.0641 & 0.27 \\
\hline Andropogon gerardii & $\mathrm{C}_{4}$ & G1 & 0.515 & 0.472 & 0.746 & 1.57 & 0.1 & 71.46 & 251.04 & 0.1961 & 0.0669 & 0.08 \\
\hline Panicum virgatum & $\mathrm{C}_{4}$ & G1 & 0.202 & 0.474 & 0.884 & 0.61 & 0.1 & 50.79 & 131.91 & 0.1359 & 0.0485 & 0.24 \\
\hline Schizachyrium scoparium & $\mathrm{C}_{4}$ & G1 & 0.534 & 0.685 & 0.697 & 0.98 & 0.11 & 62.69 & 250.78 & 0.2043 & 0.0611 & 0.31 \\
\hline Sorghastrum nutans & $\mathrm{C}_{4}$ & G1 & 0.348 & 0.522 & 0.514 & 0.98 & 0.09 & 71.76 & 201.86 & 0.4986 & 0.1439 & 0 \\
\hline Koeleria cristata & $\mathrm{C}_{3}$ & G2 & 0.476 & 0.267 & 0.556 & 0.49 & 0.1 & 55.69 & 152.26 & 0.0635 & 0.0202 & 0.29 \\
\hline Poa pratensis & $\mathrm{C}_{3}$ & G2 & 0.544 & 0.347 & 0.296 & 0.7 & 0.13 & 52.43 & 149.07 & 0.1501 & 0.0521 & 0.39 \\
\hline Stipa comata & $\mathrm{C}_{3}$ & G2 & 0.668 & 0.619 & 0.479 & 0.74 & 0.06 & 43.22 & 190.16 & 0.2413 & 0.0646 & 0.26 \\
\hline Stipa viridula & $\mathrm{C}_{3}$ & G2 & 0.602 & 0.615 & 0.358 & 0.66 & 0.1 & 53.55 & 225.76 & 1.0824 & 0.2198 & 0 \\
\hline Bouteloua curtipendula & $\mathrm{C}_{4}$ & G2 & 0.631 & 0.693 & 0.326 & 0.55 & 0.13 & 60.02 & 244.34 & 0.1628 & 0.0522 & 0.02 \\
\hline Bouteloua gracilis & $\mathrm{C}_{4}$ & G2 & 0.584 & 0.57 & 0.368 & 0.76 & 0.09 & 50.75 & 153.6 & 0.3927 & 0.0671 & 0 \\
\hline Agropyron spicatum & $\mathrm{C}_{3}$ & G3 & 0.527 & 0.749 & 0.593 & 1.01 & 0.11 & 45.85 & 168.5 & 0.7674 & 0.2222 & 0.13 \\
\hline Elymus canadensis & $\mathrm{C}_{3}$ & G3 & 0.439 & 0.567 & 0.473 & 1.09 & 0.13 & 55.18 & 190.45 & 1.348 & 0.3221 & 0.34 \\
\hline Calamovilfa Iongifolia & $\mathrm{C}_{4}$ & G3 & 0.372 & 0.298 & 0.289 & 0.68 & 0.11 & 54.66 & 262.83 & 0.3289 & 0.0756 & 0.25 \\
\hline Sporobolus cryptandrus & $\mathrm{C}_{4}$ & G3 & 0.443 & 0.508 & 0.434 & 1.05 & 0.14 & 48.14 & 185.95 & 1.3337 & 0.3761 & 0.36 \\
\hline \multicolumn{13}{|l|}{ Forbs } \\
\hline Achillea millefolium & $\mathrm{C}_{3}$ & $\mathrm{~F} 1$ & 0.411 & 0.793 & 0.968 & 1.67 & 0.14 & 39.42 & 98.14 & 0.4363 & 0.1517 & 0.92 \\
\hline Artemisia dracunculoides & $\mathrm{C}_{3}$ & $\mathrm{~F} 1$ & 0.588 & 0.91 & 0.703 & 0.39 & 0.13 & 43.2 & 146.88 & 0.8507 & 0.2529 & 0.15 \\
\hline Asclepias verticillata & $\mathrm{C}_{3}$ & $\mathrm{~F} 1$ & 0.338 & 0.744 & 0.595 & 1.07 & 0.09 & 66.14 & 123.01 & 0.4105 & 0.1241 & 0.39 \\
\hline Chrysopsis villosa & $\mathrm{C}_{3}$ & $\mathrm{~F} 1$ & 0.478 & 0.596 & 0.461 & 0.75 & 0.09 & 38.6 & 127.01 & 0.1858 & 0.0345 & 0.76 \\
\hline Cirsium arvense & $\mathrm{C}_{3}$ & $\mathrm{~F} 1$ & 0.584 & 0.769 & 0.718 & 0.98 & 0.11 & 63.31 & 114.99 & 0.2466 & 0.1083 & 0.03 \\
\hline Coreopsis lanceolata & $\mathrm{C}_{3}$ & $\mathrm{~F} 1$ & 0.317 & 0.621 & 0.618 & 0.67 & 0.11 & 52.34 & 163.83 & 0.345 & 0.0737 & 0.35 \\
\hline Gaillardia aristata & $\mathrm{C}_{3}$ & $\mathrm{~F} 1$ & 0.17 & 0.929 & 0.969 & 0.95 & 0.08 & 32.44 & 96.28 & 0.2267 & 0.075 & 0.85 \\
\hline Geum triflorum & $\mathrm{C}_{3}$ & $\mathrm{~F} 1$ & 0.41 & 0.646 & 0.703 & 0.67 & 0.08 & 53.8 & 127.38 & 0.3213 & 0.085 & 0.33 \\
\hline Helianthus rigidus & $\mathrm{C}_{3}$ & $\mathrm{~F} 1$ & 0.211 & 0.56 & 0.56 & 0.81 & 0.09 & 31.31 & 65.97 & 0.3629 & 0.0912 & 0.3 \\
\hline Lupinus perennis & $\mathrm{C}_{3}$ & $\mathrm{~F} 1$ & 1.26 & 1.027 & 1.027 & 1.19 & 0.1 & 50.36 & 98.67 & 0.6303 & 0.2251 & 1.15 \\
\hline Melilotus officinalis & $\mathrm{C}_{3}$ & $\mathrm{~F} 1$ & 0.559 & 0.877 & 0.877 & 2.78 & 0.14 & 42.94 & 82.54 & 1.2851 & 0.1579 & 0.38 \\
\hline Potentilla arguta & $\mathrm{C}_{3}$ & $\mathrm{~F} 1$ & 0.358 & 0.783 & 0.783 & 0.46 & 0.1 & 47.2 & 153.39 & 0.3926 & 0.1058 & 0.25 \\
\hline Ratibida columnifera & $\mathrm{C}_{3}$ & $\mathrm{~F} 1$ & 0.411 & 0.803 & 0.803 & 0.41 & 0.1 & 41.75 & 87.56 & 0.9931 & 0.3586 & 0.5 \\
\hline Rudbeckia hirta & $\mathrm{C}_{3}$ & $\mathrm{~F} 1$ & 0.647 & 0.723 & 0.723 & 0.64 & 0.12 & 49.59 & 113.3 & 1.0892 & 0.2979 & 0.8 \\
\hline Solidago missouriensis & $\mathrm{C}_{3}$ & $\mathrm{~F} 1$ & 0.526 & 0.729 & 0.729 & 0.69 & 0.1 & 38.33 & 264.75 & 0.0297 & 0.0025 & 0.72 \\
\hline Solidago rigida & $\mathrm{C}_{3}$ & $\mathrm{~F} 1$ & 0.245 & 0.89 & 0.89 & 1.21 & 0.1 & 59.12 & 137.05 & 0.3477 & 0.0882 & 0.42 \\
\hline Taraxacum officinale & $\mathrm{C}_{3}$ & $\mathrm{~F} 1$ & 0.348 & 0.968 & 0.912 & 0.72 & 0.12 & 53.88 & 136.76 & 0.5504 & 0.0875 & 0.61 \\
\hline Tragopogon dubius & $\mathrm{C}_{3}$ & $\mathrm{~F} 1$ & 0.578 & 0.718 & 0.968 & 0.77 & 0.1 & 41.33 & 110.82 & 0.6571 & 0.226 & 0 \\
\hline Verbena stricta & $\mathrm{C}_{3}$ & $\mathrm{~F} 1$ & 0.283 & 0.635 & 0.718 & 0.59 & 0.11 & 36.7 & 110.46 & 0.5721 & 0.1693 & 1.59 \\
\hline Vicia americana & $\mathrm{C}_{3}$ & $\mathrm{~F} 1$ & 0.356 & 0.793 & 0.635 & 1.01 & 0.08 & 38.17 & 102.65 & 0.479 & 0.1797 & 0.79 \\
\hline Allium stellatum & $\mathrm{C}_{3}$ & F2 & 0.532 & 0.617 & 0.569 & 1.85 & 0.06 & 52.2 & 141.27 & 0.119 & 0.0281 & 0.1 \\
\hline Galium boreale & $\mathrm{C}_{3}$ & F2 & 0.368 & 0.596 & 0.567 & 1.42 & 0.08 & 87.28 & 249.76 & 0.0817 & 0.0185 & 0.25 \\
\hline Artemisia frigida & $\mathrm{C}_{3}$ & F3 & 0.376 & 0.868 & 0.794 & 0.44 & 0.09 & 50.88 & 142.78 & 0.8166 & 0.0739 & 0.45 \\
\hline Aster ericoides & $\mathrm{C}_{3}$ & F3 & 0.488 & 0.693 & 0.623 & 0.96 & 0.12 & 33.08 & 142.82 & 1.315 & 0.4292 & 0.5 \\
\hline Astragalus canadensis & $\mathrm{C}_{3}$ & F3 & 0.726 & 0.476 & 0.401 & 1.97 & 0.13 & 44.36 & 144.55 & 2.9724 & 0.7098 & 0.57 \\
\hline Dalea purpurea & $\mathrm{C}_{3}$ & F3 & 0.932 & 0.849 & 0.853 & 0.9 & 0.09 & 38.93 & 121.61 & 1.9311 & 0.5538 & 0.73 \\
\hline Grindelia squarrosa & $\mathrm{C}_{3}$ & F3 & 0.449 & 0.7 & 0.58 & 0.89 & 0.14 & 39.26 & 95.99 & 0.7372 & 0.2184 & 0.82 \\
\hline Helianthus maximilliana & $\mathrm{C}_{3}$ & F3 & 0.59 & 0.479 & 0.479 & 0.92 & 0.13 & 44.66 & 97.03 & 0.717 & 0.3607 & 0.81 \\
\hline Linum perenne & $\mathrm{C}_{3}$ & F3 & 0.113 & 0.378 & 0.378 & 2.52 & 0.09 & 46.58 & 158.57 & 0.1931 & 0.0456 & 0.27 \\
\hline Oenothera biennis & $\mathrm{C}_{3}$ & F3 & 0.355 & 0.304 & 0.304 & 1.11 & 0.19 & 81 & 87.14 & 1.3504 & 0.6483 & 0.56 \\
\hline Rosa arkansana & $\mathrm{C}_{3}$ & F3 & 0.455 & 0.579 & 0.579 & 0.64 & 0.18 & 59.83 & 346.72 & 2.0071 & 0.3075 & 1.08 \\
\hline
\end{tabular}


and non-overlapping sections of the plot, avoiding areas that had been clipped in the previous $2 \mathrm{yr}$. Species richness was determined by a yearly complete survey of the entire $9-\mathrm{m}^{2}$ area of all plots (Biondini 2007). There were very few changes in the number of seeded species present in each plot after the 2000 growing season.

\section{Hyphal Sampling and Measurements}

The hyphal length measurements presented in this study were conducted in 2002 (4 yr after the plots were established). Plant biomass, as well as species and functional form richness, however, include data from 2000 to 2002.

The measurement of hyphal length required a 4-step process: 1) the hyphae had to be separated from the soil sample; 2) EAM hyphae had to be distinguished from hyphae of soil saprophytes and root pathogens; 3 ) the total length of the EAM hyphae and non-AM hyphae in the samples had to be determined; and finally, 4) this measurement had to be extrapolated to the entire plot. Hyphae were sampled at root peak biomass, taking four soil cores from each plot to a depth of $20 \mathrm{~cm}$ using a $4.8-\mathrm{cm}$ diameter core. The cores were partitioned into $0-$ to $10-\mathrm{cm}$ and 10- to $20-\mathrm{cm}$ sections and pooled so that there was one sample per plot for each partition. Pooled samples were combined and homogenized before subsamples were taken. The values determined for the samples were extrapolated to the total soil volume of the top $20 \mathrm{~cm}$, and stratified into the $0-$ to $10-\mathrm{cm}$ and $10-$ to $20-\mathrm{cm}$ depths. Soil cores were sealed in polyethylene bags and stored at $-20^{\circ} \mathrm{C}$ until analysis (Miller et al. 1995).

The soil was thawed overnight in a refrigerator at $4{ }^{\circ} \mathrm{C}$, and subsamples used to determine the dry wt to wet wt ratio. For subsampling to be effectively random, roots, hyphae, and soil had to be fragmented and mixed. This was accomplished with the use of a meat grinder with an attachment having 8-mmsized holes. Prior to grinding, roots and rhizomes larger than $1 \mathrm{~mm}$ in diameter were removed from the soil, and those smaller than $1 \mathrm{~mm}$ in diameter were detached and retained. Soil and root material less than $1 \mathrm{~mm}$ in diameter caught in the grinder was scraped out and returned to the sample. Any roots $<1 \mathrm{~mm}$ diameter that were not cut into 8 -mm segments by the meat grinder were cut using scissors and returned to the ground soil. The soil and root segments were thoroughly mixed.

The hyphae were then extracted from 5 -g subsamples using the methodology of Miller et al. (1995) and Frey and Ellis (1997) and then stained with trypan blue (1:2:2 lactic acid:glycerol:deionized water by volume with $0.6 \mathrm{~g}$ trypan blue per liter). Once hyphae were filtered and fixed on a slide with permount (Hanssen et al. 1974; Bardgett 1991; Gazey et al. 1992; Green et al. 1995; Miller et al. 1995), they were digitally imaged at $\times 100$ using a Nikon Microphot-FX ${ }^{\circledR}$ microscope attached to a Nikon DXM $1200^{\circledR}$ digital camera (Nikon Instruments Inc., Melville, NY). Seventy-six randomly chosen fields of view along nine evenly spaced transects were scored for presence or absence of hyphae, and eight fields were randomly selected for imaging. Mounts were not sufficiently thin to keep all hyphae in focus, so, when necessary, more than one image was taken of the same field to ensure that no hyphae were missed.

External hyphae were classified as AM if they were identified as belonging to the phylum Glomeromycota (Schüßler et al.
2001) based on morphology described by Mosse (1959) and Nicolson (1959). Thick-walled, large-diameter AM hyphae were mostly aseptate, rigid, and sinuous with characteristic angular projections protruding intermittently. Thin-walled, small-diameter AM hyphae were also mostly aseptate with the angular projections, but tended to be less rigid and sometimes formed long, straight ribbon-like "runner" hyphae. Both types of hyphae stained blue and were often attached to each other as well as glomerospores, roots, and vesicles. These attached structures served as useful references. EAM hyphae constituted approximately $85 \%$ of the total hyphal length in the soil. Both EAM hyphae and non-AM hyphae were quantified by digital tracing on separate images using headsup digitizing with Adobe Photoshop ${ }^{\circledR} 7.0$ software. Multiple images of the same field were digitized consecutively to ensure there was no redundancy, and the data were pooled for these images. Total hyphal lengths were measured using a root length software following Kaspar and Ewing (1997). For that purpose, we used Rootedge 2.2 ${ }^{\circledR}$ (T. Ewing, Department of Agronomy, Iowa State University, Ames, IA; T. Kaspar, National Soil Tilth Laboratory, US Department of Agriculture-Agricultural Research Service, Ames, IA).

\section{Statistical Analysis}

In experimental designs of the type used in this research, species and functional form richness are not orthogonal, independent factors because the number of functional forms is generally positively correlated with number of species. Naeem (2002) has shown, however, that the nonorthogonality problem can be solved using principal components (PC) applied to the correlation matrix of species and functional form richness. In this type of analysis, PC1 captures the combined effects of species and functional form richness, and PC2 (if statistically significant) provides information on the independent effect of functional form richness. Functional forms were assigned to each species as previously explained, and a PC was selected for further analysis if its variance $(\lambda)$ was larger than a random $\lambda$ calculated via the broken stick method (McCune and Grace 2002). The scores for the selected PCs were used as a proxy for the species and functional form richness factor in the various statistical analyses described below.

The relationships of species and functional form richness (as defined by the significant PC scores) with EAM and non-AM hyphal length were tested via regression analysis. Statistical differences in the regression slopes for the 0 - to $10-\mathrm{cm}, 10$ - to 20 $\mathrm{cm}$, and 0 - to 20-cm depths were tested using methods outlined by Snedecor and Cochran (1976, p. 349). We also ran regressions relating EAM and non-AM hyphal length to total aboveground biomass, and the aboveground biomass of the various plant functional groups (2002, and cumulative 2000-2004 biomass) using a similar approach. Because our prior extensive research with these plants showed that aboveground and root biomass were highly correlated (Johnson and Biondini 2001; Levang-Brilz and Biondini 2002; Biondini 2007, 2008), we used the 20002002 cumulative aboveground biomass as a proxy for the total buildup of root biomass in the soil. The analysis thus provides us with an indirect measurement of the extent to which EAM and non-AM hyphal length were potentially affected by the accumulation of root biomass with time. 

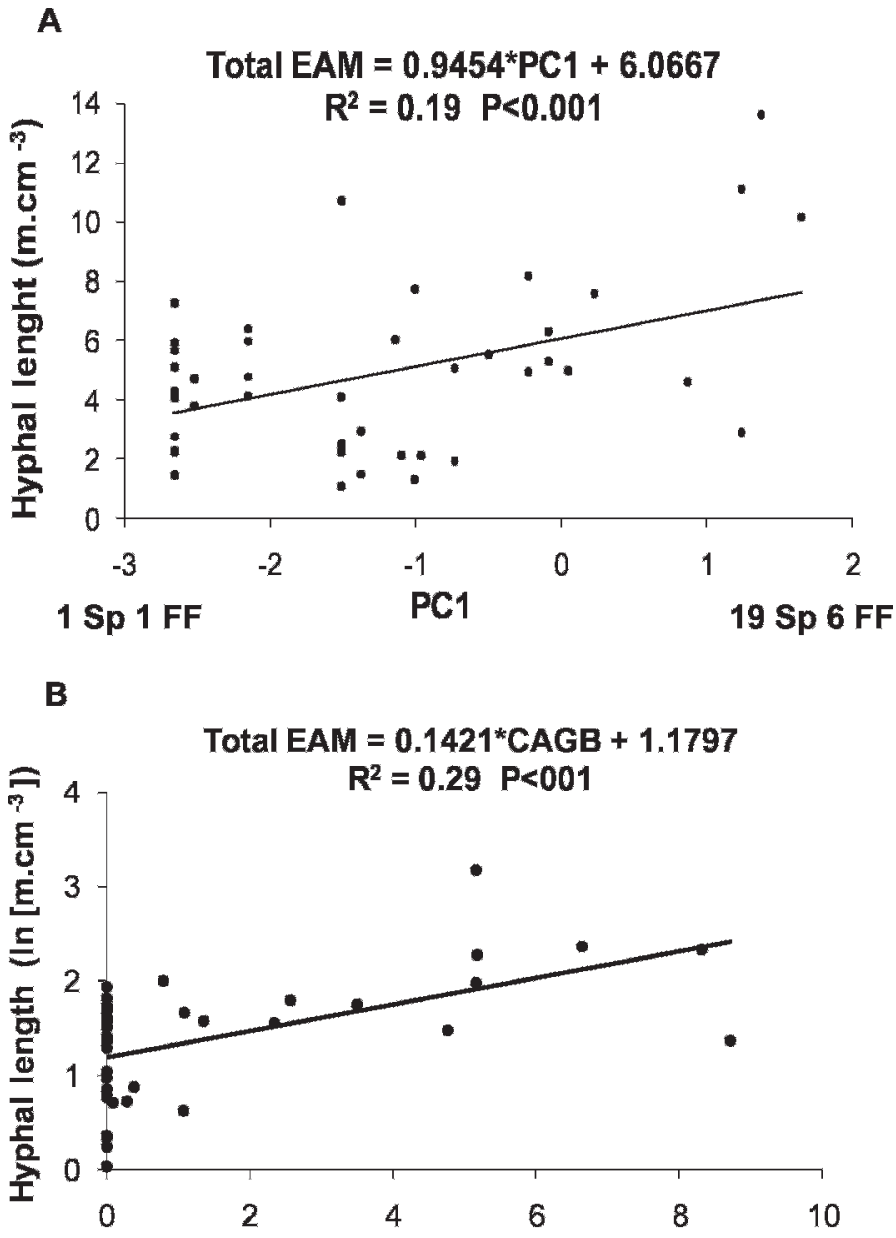

Cumulative biomass (In [g. $\left.\mathrm{m}^{-2}+1\right]$ )

Figure 1. A, Relationship between total external arbuscular mycorrhizal (EAM) hyphal length $\left(\mathrm{m} \cdot \mathrm{cm}^{-3}\right)$, and species and functional form richness (principal component 1 [PC1]). For details, see statistical section. $\mathrm{Sp}=$ species, $\mathrm{FF}=$ functional forms. $\mathbf{B}$, Relationship between the logarithm of total EAM hyphal length $\left(\mathrm{In}\left[\mathrm{m} \cdot \mathrm{cm}^{-3}\right]\right)$, and the logarithm of the cumulative biomass (2000-2002 in $\mathrm{g} \cdot \mathrm{m}^{-2}$ ) of late successional $\mathrm{C}_{4}$ grasses Andropogon gerardii, Panicum virgatum, Schizachyrium scoparium, and Sorghastrum nutans. Note: Because many plots had none of these grasses, the logarithm was calculated as In (biomass + 1).

In this type of analysis there is always an issue as to whether the species richness-mycorrhizal relationship is real or the result of a sampling effect (higher probability of selecting strongly mycorrhizal in the high species richness treatments). Although the sampling effect cannot be totally eliminated, the PC analysis described above is designed to partially mitigate the problem by decoupling the effects of richness and functional form. Furthermore, in the plots we analyzed for this experiment most of the treatments included at least one strongly mycorrhizal species. For example, based on data from Wilson and Hartnett (1998), the single species treatment had an average mycorrhizal responsiveness value of $68 \%$ (difference in mean biomass between mycorrhizal and nonmycorrhizal plants as a proportion of the mean biomass of mycorrhizal plants), and a root colonization average of $39 \%$, with six of the replications (those that included Bouteloua curtipendula
Table 2. Step-wise regression $\left(R^{2}=0.28\right.$; overall $\left.P<0.01\right)$ relating total external arbuscular mycorrhizal (EAM) hyphal length $\left(\mathrm{m} \cdot \mathrm{cm}^{-3}\right)$ to plant parameters described in Table 1. The coefficient values represent the relative importance of each variable since they were all standardized to the $0-1$ range before use (large $\beta$ means low root density).

\begin{tabular}{lccc}
\hline Variable $^{1}$ & Coefficient & Standard error & $P$ value \\
\hline NUE & 20.6 & 8.04 & 0.0142 \\
R:S & 8.23 & 3.88 & 0.0398 \\
$\beta$ & -9.39 & 2.71 & 0.0013 \\
\hline${ }^{1}$ NUE, nitrogen-use efficiency; R:S, root to shoot ratio; $\beta$, scaling constants that relate root \\
\multicolumn{2}{c}{ biomass to root lateral spread. }
\end{tabular}

[Michx.] Torr., Helianthus maximilliana Schrad., Solidago missouriensis Nutt., Sorghastrum nutans L., Sporobolus cryptandrus [Torr.] A. Gray, and Verbena stricta Vent.) having corresponding values of $92 \%$ and $43 \%$, respectively.

For each treatment we had the physiological, morphological, and growth parameters of the species involved from the functional form classification (see previous section). We used this information and stepwise regression to parse what species physiological and morphological combinations have the most impact on hyphal length under various species combinations. The approach was as follows. 1) All the physiological and morphological parameters were standardized to the $0-1$ range to make slopes comparable. 2) For each plot a weighted average (weighted by plant species biomass) of the standardized parameters was calculated. 3) These weighted averages were used as independent variables in a stepwise regression where the various components of hyphal length constituted the dependent variables (Weisberg 1980, p. 190).

\section{RESULTS}

The principal component analysis resulted in only one significant axis, PC1 $(\lambda=1.742>$ broken stick $\lambda=1.5)$, which accounted for $87 \%$ of total variance. PC1 was positively correlated with both species and functional form richness $\left(R^{2}=0.87, P<0.001\right)$. In all the analyses that follow, only PC1 was used as the variable that characterized species and functional form richness. Total EAM hyphal length $\left(\mathrm{m} \cdot \mathrm{cm}^{-3}\right)$ for the 0 - to $20-\mathrm{cm}$ soil depth was positively correlated $\left(R^{2}=0.19, P<0.001\right)$ with species and functional form richness (PC1; Fig. 1A). That relationship was driven mostly by EAM hyphal length in the 10 - to $20-\mathrm{cm}$ soil depth $\left(R^{2}=0.22, P<0.001\right)$. There were no statistically significant correlations between species and functional form richness (PC1) and non-AM hyphae at all depths $\left(R^{2}=0.007\right.$, $P=0.58$ for $0-10 \mathrm{~cm}$; and $R^{2}=0.04, P=0.18$ for $\left.10-20 \mathrm{~cm}\right)$.

Plant NUE, R:S, and root density ( $\beta$; large $\beta$ equals low root density) were also positively related to total EAM hyphal length (Table 2). When biomass was partitioned among the various plant functional groups, we found that total EAM hyphal length $(0-20 \mathrm{~cm})$ was significantly correlated (Fig. 1B) with the cumulative aboveground biomass (2000-2002; a proxy for cumulative root mass accumulation) of the $\mathrm{C}_{4}$ grasses belonging to grass functional form G1 (Table 1). This group of species (Andropogon gerardii, Panicum virgatum, Schizachyrium scoparium, and Sorghastrum nutans) is characterized 
by a high R:S, a high root surface area per unit of root biomass $(\rho)$, or both (Levang-Brilz and Biondini 2002). There were no significant relationships of EAM with aboveground peak biomass $\left(\mathrm{g} \cdot \mathrm{m}^{-2}\right)$ in 2002 , or the biomass of other functional forms (all cases $R^{2}<0.02$ and $\left.P>0.45\right)$. Non-AM hyphal length was unrelated to aboveground peak biomass in 2002, cumulative peak biomass for the 2000-2002 growing season, or the biomass of any functional form.

\section{DISCUSSION}

Results from Biondini (2007) over a 5-yr period (2000-2004) in the same experimental plots showed that 1) Aboveground biomass increased and year to year variability declined with increases in plant species and functional form richness, mostly as a result of substantial increases in minimum biomass (maximum biomass was unaffected). 2) Aboveground biomass and biomass stability increased when the species in the mixture had high relative growth rates, root density, root surface area per unit of root biomass, uptake rates of $\mathrm{N}$ or $\mathrm{P}$ per unit of root surface area, and $\mathrm{N}$-use efficiency. 3) Invasion of nonseeded species declined with increases in plant species and functional form richness. Our conjecture is that the parallel increases in EAM hyphal length shown by this study on a subset of the same experiment represent one of the potential causes for the plant biomass and stability findings of Biondini (2007). This conjecture is based in part from results from a large experiment reported by van der Heijden et al. (1998). They concluded that 1) plant biodiversity, nutrient capture, and productivity in macrocosms that simulate North American old fields increase significantly with increasing EAM hyphal length and arbuscular mycorrhizal fungal species richness; and 2) microbial interactions can drive ecosystem functions such as plant biodiversity, productivity, and variability. A substantial network of hyphae can lead to increases in the production and stability of the plant community through 1) increases in the surface area for nutrient uptake; 2) volume of soil infiltrated by EAM hyphae (hence, more reliable access to nutrients through time); 3) protection against pathogenic fungi (Singh et al. 2000; Hartnett and Wilson 2002); and 4) the interconnectivity of hyphae that can provide all plant species with additional resources (Walter et al. 1996; Hartnett and Wilson 2002; Reynolds et al. 2003). Additionally, with increased EAM uptake, plants can store surplus nutrients for later utilization (Koide 1991), thus enhancing plant biomass stability. Finally, the hyphae themselves are a portion of community production; thus, increased hyphal production also could indicate increases in total community productivity.

Our results echo those of other studies (Hooper et al. 2005; Biondini 2007), in that although functional form richness did not have an effect independent of species richness, the functional traits of the species were important (Table 2). EAM hyphal length was larger when the dominant species in the mixture had 1) high $\mathrm{N}$-use efficiency; 2) high root to shoot ratios; and 3 ) high root density $\left(\mathrm{g} \cdot \mathrm{m}^{-3}\right.$ soil $)$. Total hyphal length was also related to total and relative biomass contribution of late successional $\mathrm{C}_{4}$ grasses (Andropogon gerardii, Panicum virgatum, Schizachyrium scoparium, and Sorghastrum nutans). Late successional $\mathrm{C}_{4}$ grasses are obligatory mycorrhizal, and thus might be better adapted to an environment of intense competition for soil nutrients that develops as succession progresses (Hartnett et al. 1993; Hartnett and Wilson 1999). Numerous studies indicate that the mycorrhizal symbiosis is most important to plants when soil nutrients are limiting (Koide 1991; Marschner and Dell 1994; Johnson et al. 1997). Conversely, hyphal growth tends to decrease under fertilization (Treseder 2004).

Our results regarding late successional $\mathrm{C}_{4}$ grasses match previous ones reported by Wilson and Hartnett (1998). They showed that perennial warm-season $\mathrm{C}_{4}$ grasses and forbs tend to significantly benefit from the mycorrhizal symbiosis, whereas $\mathrm{C}_{3}$ grasses are less affected because their roots are less colonized by the AM fungi. With data from Wilson and Hartnett (1998), we calculated that three of our warm season grasses Andropogon gerardii, Panicum virgatum, and Sorghastrum nutans had mycorrhizal responsiveness (MR) of $99.4 \%$, $98.2 \%$, and $99.5 \%$, respectively, and colonization rates of $50.2 \%, 61.4 \%$, and $44.7 \%$, respectively. Of the $\mathrm{C}_{3}$ grasses and forbs tested by Wilson and Hartnett (1998) that also were in our plots the equivalent values averaged $-6.9 \%$, and $17.3 \%$ (with some species such as Bromus inermis, Hordeum jubatum L., Koeleria cristata (Lam.) Beauv., and Poa pratensis showing a very negative response to mycorrhizal infection: average MR, $-20 \%)$.

The differences in mycorrhizal responses by $\mathrm{C}_{3}$ vs. $\mathrm{C}_{4}$ grasses are in part a result of differences in their root systems. $C_{3}$ grasses tend to have highly fibrous root systems (highly branched, small diameter) and are weakly or nondependent on mycorrhizal symbiosis, whereas $\mathrm{C}_{4}$ grasses tend to have coarser root systems (less branching, larger diameter) and are obligate mycotrophs (Hetrick et al. 1990; Wilson and Hartnett 1998). An extensive analysis by Biondini (2008) of the root architecture of 1759 plants from 77 species confirm the fibrous vs. coarse root differences for $\mathrm{C}_{3}$ vs. $\mathrm{C}_{4}$ grasses used in this study. The $\mathrm{C}_{3}$ grasses had 1) an average branching constant of 2.5 vs. 1.9 for the $C_{4}$ grasses $(P<0.0001)$; and 2$)$ a scaling constant for root diameter branching of 0.83 vs. 0.87 for the $\mathrm{C}_{4}$ grasses $(P<0.0001)$. The higher root surface area per unit of root biomass $(\rho)$ of $C_{4}$ vis a vis $C_{3}$ grasses was entirely the result of higher root length per unit of root biomass (a scaling constant of 0.88 for $\mathrm{C}_{4}$ vs. 0.83 for $\mathrm{C}_{3}$ grasses, $\left.P<0.001\right)$. In summary, the $\mathrm{C}_{4}$ grasses in our study have 1) less branching and thicker roots than the $\mathrm{C}_{3}$ grass, and 2) longer root segments than the $\mathrm{C}_{3}$ grasses; this resulted in higher root surface area vis $\mathrm{a}$ vis the $\mathrm{C}_{3}$ grasses. These patterns suggest that carbon allocation to a finely branched root system with high root hair density and carbon allocation to mycorrhizal fungi might be alternative absorption strategies for acquisition of soil resources (Hetrick et al. 1990).

There is one area where our results differ from similar studies in the tallgrass prairie. Hartnett and Wilson (1999) in a 5-yr study conducted in the southern tall grass prairie found that the suppression of mycorrhizae resulted in a decrease in the abundance of $\mathrm{C}_{4}$ grasses, with a compensatory increases in the abundances of many subordinate facultative mycotrophic $\mathrm{C}_{3}$ grasses and forbs. The end result was an inverse relationship between mycorrhizae levels and species diversity because under high mycorrhizae levels, $\mathrm{C}_{4}$ grasses tended to suppresses subdominant $\mathrm{C}_{3}$ species. In the northern tall grass prairie, 
however, the vegetation is dominated by $\mathrm{C}_{3}$ rather than $\mathrm{C}_{4}$ grasses (Barker and Whitman 1988; Biondini 2007), so an increase in mycorrhizae levels should lead to increases in subdominant $\mathrm{C}_{4}$ grasses and thus a positive correlation with species diversity.

If the length of EAM hyphae in the soil is being driven by factors such as the ratio of resource availability and the plant species present, then over the long term, hyphal lengths should remain high when conditions are favorable to hyphal regeneration. Therefore, hyphal nutrient uptake is likely to be persistently greater in diverse and highly competitive latesuccessional communities, despite rapid hyphal turnover rates (Friese and Allen 1991; Staddon et al. 2003). Finally, extraradical mycelia of mycorrhizal fungi are a significant component of the terrestrial global carbon cycle (Treseder and Allen 2000; Zhu and Miller 2003), and might sequester C in soils at increasing rates as $\mathrm{CO}_{2}$ concentration rises (Sanders et al. 1998; Staddon et al. 1999; Treseder and Allen 2000). This same process also has repercussions for soil structural stability facilitated by the formation of soil water-stable aggregates (Miller and Jastrow 1992; Zhu and Miller 2003).

\section{IMPLICATIONS}

Plant community diversity and composition have potential effects on production, stability, and carbon sequestration via EAM hyphae, and therefore should be taken into consideration in grassland restoration and management. The major conclusions from this study are that in order to recover EAM hyphal length in restored northern tallgrass prairies, three factors need to be given priority: 1) achieving high levels of species and functional form richness; 2) making sure that late successional $\mathrm{C}_{4}$ grasses, such as Andropogon gerardii, Panicum virgatum, Schizachyrium scoparium, and Sorghastrum nutans are present; and 3) making sure that the seed mixture includes species that are characterized by high root to shoot ratio, high root density, and high N-use efficiency.

\section{ACKNOWLEDGMENTS}

We are grateful to Jack Norland for helping in the design and implementation of the field and laboratory experiments and to Dr Larry Reynolds for allowing us to use the computerized microscope and image analysis equipment in his laboratory. Thanks also go out to Drs R. M. Miller, E. B. Allen, and H. D. Addy for help on methods regarding hyphal extraction and morphotyping.

\section{LITERATURE CITED}

BARDGETT, R. D. 1991. The use of the membrane filter technique for comparative measurements of hyphal lengths in different grassland sites. Agriculture Ecosystems and Environment 34:115-119.

Barker, W. T., and W. C. Whitman. 1988. Vegetation of the northern Great Plains. Rangelands 10:266-272.

Biondinl, M. 2001. A three dimensional spatial model for plant competition in an heterogeneous soil environment. Ecological Modeling 142:189-225.

BıondINI, M. E. 2007. Plant diversity, production, stability, and susceptibility to invasion in restored northern tallgrass prairies (United States). Restoration Ecology 15:77-87.
BIondinI, M. E. 2008. Allometric scaling laws for water uptake by plant roots. Journal of Theoretical Biology 251:35-59.

ERIKSSON, A. 2001. Arbuscular mycorrhiza in relation to management history, soil nutrients and plant species diversity. Plant Ecology 155:129-137.

Frey, J. E., and J. R. Ellis. 1997. Relationship of soil properties and soil amendments to response of Glomus intraradices and soybeans. Canadian Journal of Botany 75:483-491.

Friese, C. F., And M. F. Allen. 1991. The spread of VA mycorrhizal fungal hyphae in the soil: inoculum types and external hyphal architecture. Mycologia 83:409-418.

Gazey, C., L. K. Aвbott, and A. D. Robson. 1992. The rate of development of mycorrhizas affects the onset of sporulation and production of external hyphae by two species of Acaulospora. Mycological Research 96:643-650.

Great Plains Flora Association. 1986. Flora of the Great Plains. Lawrence, KS USA: University Press of Kansas. 1400 p.

Green, D. C., A. Vilarino, R. Newsam, P. Jeffries, and J. C. Dodd. 1995. Quantification of mycelial development of arbuscular mycorrhizal fungi using image analysis. Mycorrhiza 5:105-113.

GRIME, J. P. 1977. Evidence for the existence of three primary strategies in plants and its relevance to ecological and evolutionary theory. American Naturalist 111:1169-1194.

Hanssen, J. F., T. F. Thingstad, and J. Goksorr. 1974. Evaluation of hyphal lengths and fungal biomass in soil by a membrane filter technique. Oikos 25:102-107.

Hartnett, D. C., B. A. D. Hetrick, G. W. T. Wilson, and D. J. Gibson. 1993. Mycorrhizal influence on intra- and interspecific neighbor interactions among co-occurring prairie grasses. Journal of Ecology 81:787-795.

Hartnett, D. C., AND G. W. T. Wilson. 1999. Mycorrhizae influence plant community structure and diversity in tallgrass prairie. Ecology 80:1187-1195.

Hartnett, D. C., and G. W. T. Wilson. 2002. The role of mycorrhizas in plant community structure and dynamics: lessons from grasslands. Ecology 80:1187-1195.

Hetrick, B. A., G. W. T. Wilson, and T. C. Todd. 1990. Differential responses of $C_{3}$ and $\mathrm{C}_{4}$ grasses to mycorrhizal symbiosis, $\mathrm{P}$ fertilization, and soil microorganisms. Canadian Journal of Botany 68:461-467.

Hoeksema, J. D., and M. W. Schwartz. 2003. Expanding comparative-advantage biological market models: contingency of mutualism on partners' resource requirements and acquisition trade-offs. Proceeding of the Royal Society of London B 270:913-919.

Hooper, D. U., F. S. Chapin III, J. J. Ewel, A. Hector, P. Inchausti, S. Lavorel, J. H. Lawton, D. M. Lodge, M. Loreau, S. Naeem, B. Schmid, H. Setälä, A. J. Symstad, J. Vandermeer, and D. A. Wardle. 2005. Effect of biodiversity on ecosystem functioning: a consensus of current knowledge. Ecological Monographs 75:3-35.

Johnson, H. A., AND M. E. BiondinI. 2001. Root morphological plasticity and nitrogen uptake of 59 plant species from the Great Plains grasslands, U.S.A. Basic and Applied Ecology 2:127-143.

Johnson, H., AND M. D. SchwaRTz. 1993. The Conservation Reserve Program: habitat for grassland birds. Great Plains Research 3:273-295.

Johnson, N. C., J. H. Graham, and F. A. Smith. 1997. Functioning of mycorrhizal associations along the mutualism-parasitism continuum. New Phytologist 135:575-585.

Jones, M. D., AND S. E. Sмith. 2004. Exploring functional definitions of mycorrhizas: are mycorrhizas always mutualisms? Canadian Journal of Botany 82:10891109.

Kaspar, T. C., And R. P. Ewing. 1997. R00TEDGE: Software for measuring root length density from desktop scanner images. Agronomy Journal 89:932-940.

KoIDE, R. T. 1991. Nutrient supply, nutrient demand and plant response to mycorrhizal infection. New Phytologist 117:365-386.

Levang-Brilz, N., AND M. E. Biondini. 2002. Growth rate, root development and nutrient uptake of 55 plant species from the Great Plains Grasslands, USA. Plant Ecology 165:117-144.

Marschner, H., And B. Dell. 1994. Nutrient uptake in mycorrhizal symbiosis. Plant and Soil 159:89-102.

McCune, B., And J. B. Grace. 2002. Analysis of ecological communities. Gleneden Beach, OR USA: MjM Software Design. 300 p. 
Miller, R. M., AND J. D. Jastrow. 1992. The application of VA mycorrhizae to ecosystem restoration and reclamation. In: M. F. Allen [ED.]. Mycorrhizal functioning: an integrative plant-fungal process. New York, NY USA: Chapman and Hall. p. 438-467.

Miller, R. M., D. R. Reinhart, And J. D. Jastrow. 1995. External hyphal production of vesicular-arbuscular mycorrhizal fungi in pasture and tallgrass prairie communities. Oecologia 103:17-23.

Mosse, B. 1959. Observations on the extra-matrical mycelium of a vesicular-arbuscular endophyte. Transaction of the British Mycological Society 42:439-448.

NaEEM, S. 2002. Disentangling the impacts of diversity on ecosystem function in combinatorial experiments. Ecology 83:2925-2935.

Nicolson, T. H. 1959. Mycorrhiza in the Gramineae. I. Vesicular-arbuscular endophytes with special reference to the external phase. Transactions of the British Mycological Society 42:421-438.

Redente, E. R., M. E. Biondini, and J. C. Moore. 1989. Observations on biomass dynamics of a crested wheatgrass and a short grass ecosystem in southern Wyoming. Journal of Range Management 42:113-117.

Reynolds, H. L., A. P. Packer, J. D. Bever, and K. Clay. 2003. Grassroots ecology: plant-microbe-soil interactions as drivers of plant community structure and dynamics. Ecology 84:2281-2291.

Sanders, I. R., R. Streitwolf-Engel, M. G. A. van der Heijden, T. Boller, and A. WiemKen. 1998. Increased allocation to external hyphae of arbuscular mycorrhizal fungi under $\mathrm{CO}_{2}$ enrichment. Oecologia 117:496-503.

Schübler, A., D. Schwarzott, and C. Walker. 2001. A new fungal phylum, the Glomeromycota: phylogeny and evolution. Mycological Research 105:14141421.

Singh, R., A. AdHoleyA, and K. G. MukeRJ. 2000. Mycorrhiza in control of soil borne pathogens. In: K. G. Mukerji, B. P. Chamola, and J. Singh [eDs.]. Mycorrhizal Biology. New York, NY USA: Kluwer Academic Publishers. p. 173-196.

Snedecor, G. W., And W. G. Cochran. 1976. Statistical Methods. 6th ed. Ames, IA, USA: The lowa State University Press. $593 \mathrm{p}$.

Spehn, E. M., A. Hector, J. Joshi, M. Scherer-Lorenzen, B. Schmid, E. Bazeley-White, C. Beierkuhnlein, M. C. Caldeira, M. Diemer, P. G. Dimitrakopoulos, J. A. Finn, H. Freitas, P. S. Giller, J. Good, R. Harris, P. Högberg, K. Huss-Danell, A. Jumpponen, J. Koricheva, W. Leadley, M. Loreau, A. Minns, C. P. H. Mulder, G. O'Donovan, S. J. Otway, C. Palmborg, J. S. Pereira, A. B. Pfisterer, A. Prinz, D. J. Read, E. D. Schulze, A. S. D. Siamantziouras, A. C. Terri, A. Y. Troumbis, F. I. Woodward, S. Yachi, and J. H. Lawtonb. 2005. Ecosystem effects of biodiversity manipulations in European grasslands. Ecological Monographs 75:35-63.

Staddon, P. L., A. H. Fitter, and J. D. Graves. 1999. Effect of elevated atmospheric $\mathrm{CO}_{2}$ on mycorrhizal colonization, external mycorrhizal hyphal production and phosphorus inflow in Plantago lanceolata and Trifolium repens in association with the arbuscular mycorrhizal fungus Glomus mosseae. Global Change Biology 5:347-358.

Staddon, P. L., C. B. Ramsey, N. Ostle, P. Ineson, and A. H. Fitter. 2003. Rapid turnover of hyphae of mycorrhizal fungi determined by AMS microanalysis of ${ }^{14} \mathrm{C}$. Science 300:1138-1140.

Tilman, D., C. L. Lehman, ANd C. E. Bristow. 1998. Diversity-stability relationships: statistical inevitability or ecological consequences. American Naturalist 151:277-282.

Tilman, D., D. Wedin, And J. Knops. 1996. Productivity and sustainability influenced by biodiversity in grassland ecosystems. Nature 379:718-720.

Treseder, K. K. 2004. A meta-analysis of mycorrhizal responses to nitrogen, phosphorus, and atmospheric $\mathrm{CO}_{2}$ in field studies. New Phytologist 164:347-355.

Treseder, K. K., And M. F. Allen. 2000. Mycorrhizal fungi have a potential role in soil carbon storage under elevated $\mathrm{CO}_{2}$ and nitrogen deposition. New Phytologist 147:189-200.

van der Heijden, M. G. A., J. N. Klironomos, M. Ursic, P. Moutoglis, R. StreitwolfEngel, T. Boller, A. Wiemken, and I. R. Sanders. 1998. Mycorrhizal fungal diversity determines plant biodiversity, ecosystem variability and productivity. Nature 396:69-71.

Walter, L. E. F., D. C. Hartnett, B. A. D. Hetrick, and A. P. Schwab. 1996. Interspecific nutrient transfer in a tallgrass prairie plant community. American Journal of Botany 83:180-184.

WeIsBerg, S. 1980. Applied linear regression. New York, NY USA: John Wiley and Sons. $281 \mathrm{p}$.

Wilson, W. T., and D. C. Hartnett. 1998. Interspecific variation in plant responses to mycorrhizal colonization in tallgrass prairie. American Journal of Botany 85:1732-1738.

Wright, S. F., and A. Upadryaya. 1998. A survey of soils for aggregate stability and glomalin, a glycoprotein produced by hyphae of arbuscular mycorrhizal fungi. Plant and Soil 198:97-107.

ZHu, Y. G., AND R. M. MıLleR. 2003. Carbon cycling by arbuscular mycorrhizal fungi in soil-plant systems. Trends in Plant Science 8:407-409. 